Article

\title{
Ecofaith: Reading Scripture in an Era of Ecological Crisis
}

\section{J. J. Johnson Leese}

School of Theology, Seattle Pacific University and Seminary, Seattle, WA 98119, USA; leesej@spu.edu

Received: 4 February 2019; Accepted: 1 March 2019; Published: 4 March 2019

\begin{abstract}
This essay outlines the emerging field of ecological theology (ecotheology) with a primary focus on the methods of ecological hermeneutics developed by biblical scholars, ethicists, and theologians. This relatively new approach to reading ancient sacred texts has emerged in tandem with, and partially as a result of, increased public, political, and scientific consensus on the impacts of anthropogenic global warming and the ranging environmentally related effects (e.g., reduction of biodiversity and ecosystems, deforestation, loss of fertile lands, and so forth). The demands of our current context have challenged scholars to consider how religious anthropocentric worldviews have influenced historical readings of the Bible in ways that have contributed to the crisis and constricted the ecological contours of the ancient text. In order to place these developments within a broader historical context, the first section summarizes the history and trajectory of ecological hermeneutics over the past four decades. The main section of this work outlines and summarizes the different types of reading strategies being considered and debated among scholars today and includes promising examples of ecocritical readings of biblical texts. These readings are based on a constructive and critical engagement of ancient texts in light of the modern environmental challenges.
\end{abstract}

Keywords: Bible; New Testament; ecotheology; hermeneutics; anthropocentric; hierarchical dualism; environment; nature; creation

\section{Introduction}

How are Christians to read Scripture in an era where the earth is "groaning in travail" (Rom. 8:22)? What is the relationship of the triune God to the cosmos that humans call home? Is the Spirit of God breathing life into the natural world? These types of questions reflect recent trends in the related disciplines of theology, biblical interpretation, and ethics, trends that attest to the attraction of reframing theological frameworks and biblical interpretation in light of environmental and ecological considerations. Because of the introductory nature of this article and the complexity of each discipline, I use the terms ecotheology and ecological hermeneutics broadly, acknowledging that ecotheologians and biblical scholars utilize distinct methods and engage Scripture to varying degrees. Ecotheology has quickly arisen as a respected discipline of theological inquiry, while fresh hermeneutical methods have concurrently been employed by biblical scholars, demonstrating the interrelated nature of these trends. ${ }^{1}$ Evidence of the ecumenical appeal for such readings is reflected in the expanding scholarship and the growing praxis among Christians to care for the creation. This trend is present in all the major branches of Christianity and ecumenical organizations: examples include statements by the World Council of Churches (WCC) and the Evangelical Environment Network, initiatives by most

1 Attempting such a broad methodology will inevitably collapse some of the complexity of these distinct fields and perhaps create tension for some readers. The intent is to establish overarching developments that have impacted, to varying degrees, theology and biblical studies. 
mainline Protestant traditions, and the emergence of faith-based NGO's with environmental concerns. ${ }^{2}$ Of recent note is the highly acclaimed 2015 encyclical by Pope Francis, Laudato Si': On Care for Our Common Home. ${ }^{3}$

In order to situate this relatively new development within a broader historical context, this essay will first provide a brief overview of the trajectory of ecological hermeneutics over the past four decades. ${ }^{4}$ This is followed by the main section of this work, which summarizes a variety of ecocritical reading strategies and hermeneutical approaches to Scripture. The categories outlined below are neither exhaustive, nor preferential to any one approach, but alternatively are representative of various strategies employed by a majority of ecotheological readings of Scripture. Although the focus of this journal issue is on New Testament trends, included throughout the discussion are examples of key creation texts from the Hebrew Bible as well. This is due in part to the intertextual nature of scriptural writings and the models of interpretation that these key texts illustrate.

\section{Historical Factors Contributing to Ecological Hermeneutics}

Clearly the most significant development contributing to a reorientation of reading Scripture with ecological sensitivities results from increased scientific findings highlighting the environmental crisis facing the planet earth. Increased public, political, and scientific consensus on the impacts of global warming and the ranging environmentally related effects (e.g., reduction of biodiversity and ecosystems, deforestation, loss of fertile lands, and so forth) have contributed toward environmental issues becoming a central priority for the international community. The crisis, considered to be overwhelmingly caused by human patterns and habits, has led scientists to coin the term Anthropocene as a technical descriptor for the current geological epoch. These sobering developments become even more disturbing when findings affirm that the impact of climate change patterns disproportionately affect the most underprivileged and vulnerable in the world. The culmination of these factors and others highlights the complexity of this global challenge. In response many religious communities are reassessing historical teachings and praxis and collaborating together, making ecology a topic of religious urgency. 5

This reassessment was thrust upon Christians by a now famous article, "The Historical Roots of Our Ecologic Crisis", by historian Lynn White Jr., in 1967. His assessment focuses primarily on how anthropocentric interpretations of Genesis 1 have given priority to humanity as uniquely made in God's image and the endorsement "to have dominion over" all the earth (Gen. 1:26-28), a reading he claims exacerbated and accelerated exploitation of nature. White's underlying thesis is that for most of the history of Christian interpretation, Christians have read Scripture in such a way that "not only established a dualism of man and nature but also insisted that it is God's will that man exploit nature for his proper ends" (White 1967, p. 1205). He further draws a direct correlation between the conquests of nature characteristic of technological advancements of the industrial era and domineering patterns of Christian existence such as during the period of colonialization: "Both our present science and our present technology are so tinctured with orthodox Christian arrogance toward nature that no solution for our ecological crisis can be expected from them alone" (White 1967, p. 1205-6). White's

2 See, for example, the list of Christian Environmental Activism organizations in Deane-Drummond (Deane-Drummond 2017, pp. 131-34). For an example of a voluminous collection of articles resulting from a series of conferences in 1996 through 1998 on the world and ecology see Christianity and Ecology: Seeing the Well-Being of Earth and Humans (Hessel and Ruether 2000).

3 Eastern Orthodox theology has been more attentive to the spiritual connections with the material realm than Western and Protestant traditions. Due to the different trajectory of the Orthodox traditions, they will not be addressed in this article. For an overview, see the recent contribution of Elizabeth Theokritoff (Theokritoff 2017).

4 This brief overview is neither comprehensive nor complete. For a lengthy and critical discussion of a historical genealogy, see Ecotheology and the Practice of Hope (Dalton and Simmons 2010, pp. 19-38).

5 Within the literature, a variety of terms are employed. The terms nature or environment more generally refer to our surroundings, whereas the term ecology suggests all living organisms that find their home in the earth, inclusive of humanity. In order to highlight the interconnection of humanity with all living organisms, I primarily use the term ecology in this essay. For a discussion of the importance of terminology in this field see Wirzba (2015). 
stinging critique of Christianity generated a proliferation of responses, ranging from sharp derision to reflective consideration. In spite of this range of critique, White's generative thesis remains a historically significant point of reference that set the trajectory for biblical and theological re-readings of Christian Scripture. ${ }^{6}$

One common consideration of any reading of Scripture is that biblical interpretation is an act of re-appropriation that considers the ancient text in light of the context of the human reader. Therefore, an ecological hermeneutic must consciously establish a link between the biblical narrative and the pressing ecological questions of our current context. Such an approach requires a paradigmatic shift establishing ecology and the ecocrisis as a bona fide hermeneutical lens for reading Scripture, a lens that ideally enables interpretation to inform praxis. The need for this shift is succinctly expressed by author Wendell Berry: "Our predicament now, I believe, requires us to learn to read and understand the Bible in the light of the present fact of Creation" (Berry 2002, p. 306).

Employing eco-sensitive lenses to the interpretive process has shaped emerging reading strategies in ecotheology. What have resulted are studies that concentrate primarily on identifying texts that include themes or teachings about nature or alternatively have an explicit theology of creation (e.g., Gen. 1-2; 6-9; Lev. 25; Job 37-39; Pss. 8; 19; 24; 98; 104; Isa. 9-11; Matt. 6:28-30; Rom. 8:18-23; Col. 1; and Rev. 21-22). Demonstrating a more comprehensive approach, The Green Bible represents attempts to highlight every biblical reference to other-than-human creation (e.g., soil, earth, plants, air, mountains, rivers, trees, etc.). In helpful ways, such hermeneutical approaches affirm that creation themes and motifs are not limited to the early chapters of the Bible and reflect a growing sensitivity to the degree to which the agrarian context of the ancient world influenced biblical writers, writers who reflect a keen sense of their place. Although the evangelical Christian community has been relatively late in contributing toward ecotheological readings of the Bible, Calvin DeWitt represents one of the exceptions. Trained as an ecologist and environmentalist scientist, he has focused primarily on outlining a biblically grounded stewardship ethic of caring for the earth. For those advocating for such a framework, his more recent works provide a robust set of principles for consideration (DeWitt 2000, pp. 65-67).

In subsequent years, these earlier approaches to biblical exegesis, theology, and praxis have been critiqued from at least three perspectives. One critique is that these approaches are too narrowly focused, with the effect of relegating ecological motifs to marginal themes of the biblical narrative or as isolated within key texts. In keeping with historical readings, non-human elements of the text effectively function as a backdrop or stage for the more important divine-human drama to unfold (Watson 2010, pp. 127-30). A second and formidable critique follows the lead of both liberation and feminist interpretive traditions. In both instances, their struggle with the ancient text has led them to acknowledge that the Bible is not unbiased, nor does it speak in a univocal voice. Although some texts side with the economically disadvantaged, oppressed, and women, other texts reflect the ruling class and/or the patriarchal interests of the authors, who themselves were shaped by the historical realities of their settings. When these inherent limitations of Scripture are taken into consideration, it is judged as insufficient to simply gather relevant texts or summarize "what the Bible says" about ecology. A final critique considers certain aspects of stewardship models as inadequate. Central to stewardship models is the responsibility placed on humans as those granted by God to care for the creation. In this framework humans retain a position of being the "subject" while all created matter is relegated to "object", a framework considered deficient by many (Bauckham 2010, pp. 1-10; Berry 2006). An alternative model called ecojustice rejects the notion of earth as the object of human discipleship, emphasizing rather the full integrity and value of creation completely apart from

6 The significance of White's article is demonstrated by the numerous times it is referenced in articles (e.g., Horrell et al. 2010). In light of the 50th anniversary of its publication, other more detailed responses have emerged (e.g., Jenkins 2009). 
humanity. This model is often considered as having been first articulated by the Earth Bible project, discussed further below.

In light of these critiques and realities, a new era of engaged discussion about what constitutes a more robust form of ecological hermeneutics and praxis has emerged, represented in part by the burgeoning corpus of ecotheological readings of Scripture. The expanding field of resources attests to the appeal and relevance of ecological hermeneutics for our day. Our unique challenges and questions demand a more sophisticated and nuanced constructive process of biblical interpretation, readings that are predicated on the ancient text yet shaped by various factors, including the modern context, traditions of reading, personal experience, reason, and other relevant epistemological sources. It seems inevitable that thoughtful encounters between modern reader and Scripture will determine that some texts are objectionable in light of modern insights on the current state of the earth community.

For example, the Earth Bible project, based in Australia, has advocated for a reconstructive approach that goes beyond simply retrieving eco-friendly texts. Central to this paradigmatic shift is the insistence that a posture of recovery, suspicion, and even resistance is necessary in the interpretive process. To appeal to a broad ecumenical audience and in dialogue with ecologists, the Earth Bible team crafted a set of ecojustice principles that approach the interpretive practices from the perspective of the earth: intrinsic worth of all creatures, interconnectedness of all things, creation's capacity of voice, purpose in each component of creation, role of humans as mutual custodianship, and resistance of earth to injustices (Habel and Wurst 2000). These principles establish earth as subject and are set forth as a normative guide for theological and biblical interpretation, pioneering a new era for fresh dialogue and discussion. ${ }^{7}$ Although more limited in scope, the Exeter project, funded by the Arts and Humanities Research Council of the UK (AHRC), established an interdisciplinary research group that through focused collaboration produced important scholarship. One particularly valuable contribution is a 2010 publication, Ecological Hermeneutics: Biblical, Historical and Theological Perspectives, which is the culmination of a multi-year project by over twenty scholars (Horrell et al. 2010). Scholars associated with both of these organizations have also been active contributors to the initiatives and papers presented at the Seminar on Ecological Hermeneutics hosted by the Society for Biblical Literature. Just as Lynn White's article helped to shape the contours of the earliest interpretive considerations, the Earth Bible project and the Exeter project in tandem with liberation and ecofeminist hermeneutical perspectives have fostered a setting fertile for the growth of eco-scholarship. Although the limitations of a journal article do not allow for a comprehensive analysis of all ecotheological trends, what follows is a representative listing of strategies and principles present in the majority of ecotheological scholarship. ${ }^{8}$

\section{Representative Strategies and Approaches to Ecological Hermeneutics}

\subsection{Identifying Anthropocentrism}

One fundamental consideration for ecocritical readers of the text is to acknowledge and reassess anthropocentric bias in biblical texts, biblical interpretation, and praxis, a bias that is particularly evident in the Western Christian tradition. This recognition does not deny that the biblical text, by its very nature, is to some degree both anthropotopic (a text having humanity as the central theme or topos) and androcentric (a text having a male person as the central theme or topos). Scriptural texts were written by male persons for the Israelite and early Christian communities, reflecting topics of human interest from the ancient world. In relationship to this, Paul J. Schutz reflects, “Theology must continue to wrestle with ideas like the imago Dei and with the priority of God's self-communication to human creatures in the tradition" (Schutz 2018, p. 15). Ancient texts do not directly address modern epistemology, concerns, and/or questions on any number of topics, including the ecocrisis.

7 For contributions from this perspective, see particularly the Earth Bible Series and the Earth Bible Commentaries (Habel 2000, 2001; Habel and Wurst 2000, 2001; Habel and Balabanski 2002).

8 Other categories are identified with various emphasis (e.g., Horrell 2010; Habel 2009). 
Therefore to critically evaluate Scripture with criteria of modern questions and concerns is simplistic and anachronistic. Nevertheless, acknowledging that anthropocentric habits of thought are present, and at times problematic, remains an essential step in biblical interpretation. Bias presupposes that humans are the most important part of creation and has clearly influenced historical readings of Scripture. This de facto results, either consciously or not, in a devaluation of the other-than-human created matter and/or the eclipse of non-human characters in biblical interpretation.

Readers who are sensitive to these considerations approach biblical exegesis anticipating that the text contains hidden ecological themes and/or novel theological insight. One step in the process is ascertaining to what degree any given text may have a history of misreadings. In these cases, interpreters attempt to recover the text from incomplete or inadequate readings while simultaneously identifying contours of the text formerly neglected or completely overlooked. One example of such an approach is the basis for the book Behold the Lilies: Jesus and the Contemplation of Nature, written by veteran ecotheologian Paul Santmire. His thesis is that the command of Jesus "Behold the lilies" in the Sermon on the Mount (Matt. 6:28) is no less an imperative for disciples than, for example, "Follow me" (e.g., Matt. 4:19). Former interpretive traditions almost exclusively focus on the words that announce God's provision of clothing for humans in the wider context of direction about not worrying. Santmire's careful exegetical work highlights the intensity of Jesus' use of the imperative and the lexical background to the Greek term merimnao ( $\mu \varepsilon \varrho \iota \mu v \alpha \dot{\omega})$ ), a word used only here in the Bible that has the common meaning of "examine closely", or "scrutinize", in other literature. This usage becomes the basis for Santmire's preference for the translation "behold." In the phrase "behold the lilies", followers of Jesus are called to contemplate the glorious, beautiful flowers in the fields, for as the text further explains, "Even Solomon, in all his glory, was not arrayed like one of these" (Matt. 6:29). Santmire suggests that this command is an invitation to readers "to behold nature more generally or to contemplate nature. This implies ... to celebrate the integrity of nature, apart from human-centered values" (Santmire 2017, p. 6). This approach is sometimes identified as uncovering an "eternal truth" of a text. In this case, a flower is identified as mysterious and captivating, evoking wonder and delight in the one who contemplates. Another way to approach this text is by focusing on the eternal truth of the interdependence of all life. From this perspective Richard Bauckham writes,

What we have in common with the lilies of the field is not just that we are creatures of God, but that we are fellow-members of the community of God's creation, sharing the same Earth, affected by the processes of the Earth, affecting the processes that affect each other, with common interests at least in life and flourishing, with the common end of glorifying the creator. (Bauckham 2010, p. 88)

\subsection{Awareness of Spirit-Nature Dualism}

Awareness of anthropocentric bias has also heightened attention given to the prevalence of a Spirit-nature dualism and the degree to which it has plagued Western worldviews from antiquity to the modern day. Early Gnostic dualistic frameworks were based on a hierarchy that reinforced opposing spheres of reality as separate and unequal; spiritual elements were considered sacred, and created matter was relegated to the sphere of the profane. Although Gnostic theology was eventually determined unorthodox, remnants of this thinking remain in philosophical and theological frameworks in modernity. ${ }^{9}$ Ecofeminists have contributed significantly to our understanding of how interlocking dualisms prevalent in patriarchal Western culture and thought have functioned to legitimize forms of domination in the name of differences of gender, race, class, education, culture, and species. Elizabeth

9 For a more extensive overview of the Gnostic hierarchical dualism as it relates to the Spirit and created matter, see Christ, Creation and the Cosmic Goal of Redemption: A Study of Pauline Creation Theology as Read by Irenaeus and Applied to Ecotheology (Leese 2018, pp. 131-88). 
Johnson suggests that the feminist insights of Rosemary Radford Ruether, Sallie McFague, and others provide a critical link between the exploitation of the earth and the exploitation of women:

In terms of the three basic relationships that shape an ecological ethic, this results in a view in which humanity is detached from and more important than nature; man is separate from and more valuable than woman; God is disconnected from the world, utterly and simply transcendent over it, as well as more significant than it. Hierarchical dualism delivers a two-tiered vision of reality that privileges the elite half of a pair and subordinates the other, which is thought to have little or no intrinsic value of its own but exists only to be of use to the higher. (Johnson 1993, pp. 10-11)

The socially constructed reality of hierarchical dualism is deconstructed further by the study of ecology, which is concerned with the dynamic interrelationship of diverse organisms and their ability to coexist within a given environment. The study of ecology affirms that human beings are but one species in the ecosystem, share the earth as home with all other living organisms, and are completely dependent on the ongoing health of the ecosystem for survival. Linking the scientific study of ecology with theological constructs, it is helpful to see how the term ecology is etymologically derived from the Greek term oikos, meaning "house" or household", which is related to the term oikonomia, understood as "stewardship" or "management" (Conradie 2007). Theologically these terms describe the divine economy of the triune God as encompassing the creation (e.g., Eph. 1:10), with Christians as members of the household of God (Eph. 2:19-22). Biblical terms such as earth (gēe), nature (physis), and creation (ktisis) reference different elements of creation, depending on the broader context, often inclusive of all living organisms, including humanity.

Readers attentive to anthropocentric bias and sensitive to the function of hierarchical dualism in ancient texts and historical interpretations of Scripture are in a position to retrieve and construct a new ecological vision from the text. For example, historical readings of texts such as Genesis 1:26-28 and Psalm 8 assume a hierarchy of relationships, with God as the transcendent Creator of all things, humanity as subject/ruler of all things, and the earth as an object of conquest or, more recently, as a commodity for consumption. Such approaches contribute to a sense of alienation between human beings and the rest of creation and in some contexts have justified unfettered human domination over the creation.

Ecotheological readings of these same texts have significantly challenged such readings by clarifying the meaning of Hebrew terms typically translated as "to rule" and "to have dominion" (e.g., radah, kabash) identifying features of the text formerly missed, and reading Genesis 2 as a complementary creation narrative. For example, the seven repetitions of the phrase "And God saw that it was good (tob)" (Gen. 1:4, 10, 12, 18, 21, 25, 31) affirm the integrity, value, and beauty of creation completely apart from humanity. This supports one of the six principles of the Earth Bible project while fostering an awareness of the ecocentric and theocentric consciousness in these texts. Along with many other Old Testament scholars, Ellen Davis reads the priestly creation account as poetry understanding the charge given to humanity "Be fruitful and multiply, and fill the earth and subdue it; and have dominion over ... " (Gen. 1:28) as a directive for humans to practice skilled mastery within the broader context of the blessing of animals (Gen. 1:22) and the divine gift of land provided to all creatures by a loving Creator God (Gen. 1:29-30). This language functions to establish a unique role for humanity while affirming a sense of communal membership with all creatures. The overall literary structure is theocentric, with the earth as the primary subject and co-creator with God (Davis 2009, pp. 53-65). When this creation narrative (Gen. 1) is read alongside the second creation narrative (Gen. 2:4b-3:24), these themes become even more prominent. Both Adam ('adam) and the living animals and birds have their source of being from the earth/soil (ha'adam; Gen. 2:7, 19). The Hebrew wordplay between Adam and the earth/soil highlights the kinship connection of humanity with created matter. These readings align with the study of ecology and agrarian experience of the land. Both perspectives affirm the interconnectedness that humanity shares with other organisms and ecosystems. Richard 
Bauckham laments that humanity "somewhere forgot their own creatureliness, their embeddedness within creation, their interdependence with other creatures" (Bauckham 2010, p. 11).

Another method to highlight ecological contours of a text is to identify a feature of the creation narrative formerly downplayed or ignored. In contrast to traditional readings of Genesis 1 that identify humanity as the climax of creation, Jürgen Moltmann correctly identifies Sabbath as the crown of creation. In this text, Sabbath functions in at least four specific ways: to decenter both humanity and work, to become the point of orientation for all creation, to undercut the utilitarian economic valuation of resources, and to embody sacred time, anticipating the final eschatological indwelling of God in creation (Moltmann 1985). ${ }^{10}$ Norman Wirzba is one of many scholars who have followed the lead of Moltmann by developing Sabbath theology as one key principle of the ecology of the Bible (Wirzba 2006).

\subsection{Listening to the Voice of Creation and the Experts Who Speak on Its Behalf}

Another major principle developing from the earliest eco-readings is the need to listen carefully to the voice of creation in the text. This component of ecological hermeneutics is a foundational principle promoted by the Earth Bible project, resulting in a number of scholarly works. This practice approaches all other-than-human components of the universe as a "subject" affirming creation's intrinsic integrity and worth apart from any relationship with humanity. Unlike former readings that relegated nature to an object or theme, the earth here is "capable of raising its voice in celebration and against injustice" (Habel 2008, p. 2). The theme of the earth rejoicing toward the Creator and mourning, typically in response to human wrongdoing, is frequent in the Psalms and Prophets (e.g., Pss. 19:1-3; 97:6; 98:7-8; Isa. 24:4; Jer. 4:28; 12:4) and appears in the New Testament as well (e.g., Phil. 2:10; Rom. 8:21-23; Rev. 5:13). Such expressions have typically been considered purely metaphorical or poetic since humans stand as uniquely able to express praise consciously through words. The human inability to comprehend should not detract, however, from the possibilities of other-than-human creatures' capacity to also give glory to God, even if that capacity depends on their unique created capacities of expression. Richard Bauckham's suggestion captures something of this mystery: "The Bible has de-divinized nature, but it has not de-sacralized nature. Nature remains sacred in the sense that it belongs to God, exists for the glory of God, even reflects the glory of God, as humans also do" (Bauckham 2011, p. 13).

The acknowledgment of creation's capacity to reflect God's glory has contributed to a renewed interest in approaching creation as a revelation of the triune God, historically referred to as natural theology. ${ }^{11}$ The connection of nature to revelation of God has informed doctrinal and moral considerations for much of Christian history. The sentiment of Basil of Caesarea reflects common theological reflections on texts such as Psalm 19:1 and Romans 1:20: "I want creation to awaken such a profound admiration in you, that in every place, whatever plants you may contemplate, you are overcome by a living remembrance of the Creator."12 Texts such as Job 12:7-9 invite the human to turn to animals, birds, plants, and fish for instruction; a text that prompts the interest of ecotheologians. In Proverbs 6:6-9 humans are exhorted to consider "the ways of the ant", and the New Testament affirms that "all things" come through Jesus Christ (John 1:1-3; Col. 1:15-20). These assertions provide glimpses of how the creation itself, when properly viewed, direct humans toward God.

In attempts to discern a process to hear the voice of creation, biblical and theological scholars have increasingly valued and encouraged interdisciplinary collaboration with those who speak on its behalf, particularly experts in relevant scientific disciplines. For example, in Ask the Beasts: Darwin and the God

10 For a succinct summary of Moltmann's contribution to ecological hermeneutics, see Jürgen Moltmann's Ecological Hermeneutic. Ecological Hermeneutics: Biblical, Historical and Theological Perspectives (Law 2010).

11 I am not addressing the broad topic of natural theology in this discussion. For a collection of important historical, philosophical, and scientific perspectives on natural theology, see The Oxford Handbook of Natural Theology (Manning 2013).

12 Basil, Hexaemeron 5.2 (SC 26:284). 
of Love, Elizabeth Johnson methodologically places two classic works in dialogue, Charles Darwin's account of the origin of species and the Christian confession found in the Nicene Creed (Johnson 2014). What results is an excellent example of an enriched and expanded reading of Scripture in light of the contours of scientific inquiry. Drawing more narrowly upon collaboration with agrarian practitioners, in Scripture, Culture and Agriculture: An Agrarian Reading of the Bible, Ellen Davis demonstrates not only how the land and agrarian practices are a major topic throughout the Hebrew Bible but also how the relationship with the land makes up an essential aspect of the Israelites' faith and relationship with God (Davis 2009). Ecological themes such as kinship with the land and the interconnectedness of all creation come into sharper focus when one reads Scripture from an agrarian perspective. In a similar vein, recent explorations of critical animal studies within the Bible have resulted in fascinating scholarship identifying new insights of otherwise overlooked texts. ${ }^{13}$ A final example of the fruit of interdisciplinary collaboration is Seven Pillars of Creation: The Bible, Science and the Ecology of Wonder by William Brown. In the introduction, Brown outlines his approach: "I propose a tour of the biblical contours of creation conducted in conversation with science ... to recapture something of the awe that fostered the spirit of inquiry among the ancients and today ignites the vital spark of wonder that drives the best science" (Brown 2010, p. 5). His exegetical and theological work on key Old Testament texts masterfully demonstrates how scientific findings infuse new exegetical and theological insights.

\subsection{Reconceptualization of Theological Frameworks}

A notable development emerging as a result of ecotheological approaches to Scripture is a reconceptualization of traditional theological frameworks such as soteriology, pneumatology, and eschatology. The work of Ernst M. Conradie helpfully outlines how doctrinal formulation, in a way similar to the interpretation of any individual text, is a constructive exercise shaped by multiple factors. The selection of a cluster of texts read from within a given historical context and tradition of interpretation shapes doctrinal constructs that play a crucial role in shaping faith traditions. Within times of rapid historical, social, economic, and scientific change, received doctrinal constructions may naturally be considered inadequate to address a new context. We have seen this transpire as the efficacy of the received doctrinal categories of soteriology, pneumatology, and eschatology have been called into question in light of the contemporary environmental crisis (Conradie 2006).

As general awareness of environmental concerns has grown within society, Old Testament theologians have become more cognizant of the priority given to the doctrine of redemption over the doctrine of creation; this awareness has prompted consideration for new constructions. For example, in his Old Testament theology, R. Knierim identifies a paradigmatic shift of emphasis: "Yahweh is not the God of creation because God is the God of the humans or of human history. The most universal aspect of Yahweh's dominion is not human history. It is the creation and sustenance of the world." (Knierim 1995, p. 40). Likewise Terence Fretheim suggests: "God's work in the world must be viewed in and through a universal frame of reference. That the Bible begins with Genesis, not Exodus, with creation, not redemption, is of immeasurable importance for understanding all that follows" (Fretheim 2005, p. xiv).

Similarly, New Testament scholars have begun to question the adequacy of dominant soteriological constructs that focus almost entirely on individual human salvation from sin. These frameworks were inherited in part from the preoccupation among Reformation scholars on issues of human salvation and exasperated by the tendency in the modern world to relegate nature to the sphere of science. This bifurcation led to reducing theology's compass to issues of human faith. Through a critical assessment of narrowly focused soteriological models, scholars have rediscovered premodern readings of Scripture characterized more by a vision of the whole creation, what Paul Santmire refers

13 See for example, the fascinating work of Ken Stone (Stone 2017). 
to as a "universalizing interpretive frame of reference" (Santmire 2000, p. 30). ${ }^{14}$ By identifying anthropocentric bias, New Testament scholars are expanding the central doctrine of soteriology by exploring the variety of ways that salvation (sōtēria, sōzo) is conceived in the New Testament. In addition to human reconciliation to God, sōtēria means to "heal, bring peace, rescue, reconcile, and restore" (Snyder and Scandrett 2011).

It is true that one cannot go to any one set of texts in the Gospels to identify a clear theology of creation as it relates to the theology of redemption, yet the teachings of Jesus presuppose many components of creation theology of the Hebrew Bible. God is understood as Creator of all things (Matt. 19:9; Mark 10:6), cares for creation (Matt. 6:26, 28-30; 10:29-31; cf. Luke 12:6-7; 12:24, 27-28), and is declared the "Lord of heaven and earth" (Matt. 11:25; Luke 10:21). Of special relevance is how the Gospels portray the kingdom of God by drawing upon Old Testament prophetic anticipations of the reign of God, a reign inaugurated in Jesus and one that extends beyond the saving of human souls. The healing miracles of Jesus of Nazareth provide a testimony to physical restoration as a sign of the kingdom. Some of Jesus' interactions with or in nature anticipate prophetic visions for a full restoration of humanity with the other-than-human world: chaotic waters stilled (Mark 4:35-41; cf. Job 26:12; Isa. 27:1; Rev. 21:1) and wild animals at peace (Mark 1:13; cf. Isa. 11:6-9; see Bauckham 2011, pp. 70-78). In both Matthew and Luke, the words of Jesus referencing the healing of humans alludes to Isaiah 35, which links the transformation of nature with the healing of the deaf, lame, and dumb. The teaching of Jesus brings physical, spiritual, and social healing to broken people and anticipates an eschatological wholeness to a broken creation (Bauckham 2011, pp. 63-132).

Kingdom of God language prominent in the Gospels is paralleled by Paul's understanding of the cosmic work of God in the risen Christ as the inauguration of the new creation (Gal. 6:15; 2 Cor. 5:17). This terminology is unique to Paul and has ignited a lengthy debate about the scope of what Paul intends with this phrase. Scholars disagree on whether Paul intends new creation to be a reference to individual humans, the Christian community, or the cosmos. ${ }^{15}$ Today, the majority of Pauline scholars conclude that based on Isaianic influences, the presence of key apocalyptic themes, and key linguistic considerations, Paul intends new creation to reference a universal dimension of redemption. Such a universal scope of Christ in both creation and redemption comes together in texts such as Colossians 1:15-20. This dense text establishes Christ as the "firstborn before all creation" (Col. 1:15) and Christ as the "firstborn from the dead" (Col. 1:18). Such claims identify Christ as the source and end of the totality of creation. Between these two strophes the church is identified as a new community (Col. 1:17-18a) empowered to continue the reconciling work of God within the creation (Col. 1:12-14 and 1:21-23). Romans 8 has been highlighted as perhaps the most explicit New Testament text linking the reconciling and redemptive work of Christ with not only humanity but all of creation. In this text the groaning, enslavement, hope for redemption, and freedom of the creation are linked to the fate of humanity: "for the creation was subjected to futility ... in hope that the creation itself will be set free from its bondage to decay and will obtain the glory of the children of God. We know that the whole creation has been groaning in labor pains until now; and not only the creation, but we ourselves, who have the first fruits of the Spirit, groan inwardly while we wait for adoption, the redemption of our bodies" (Rom. 8:20-23). Howard A. Snyder captures the ecological implications from texts such as these:

God's economy is more than salvation as commonly understood, more than creation healed. It is creation flourishing unendingly to God's glory. God's work is not just restorative; it is creative, generative, beautifully bountiful. Salvation is not just reversing the direction, not

14 For an insightful overview of premodern readings that inform ecotheology, see The Travail of Nature: The Ambiguous Ecological Promise of Christian Theology (Santmire 1985).

15 For a thorough review of the interpretive options, see Christ, Creation and the Cosmic Goal of Redemption: A Study of Pauline Creation Theology as Read by Irenaeus and Applied to Ecotheology (Leese 2018, pp. 23-60). 
just returning to the starting point. The plan is to liberate all creation for God's original and unending project. (Snyder and Scandrett 2011, p. 108)

As with the reconstruction of soteriological models, considerable energy has been given to eschatological texts that are widely regarded as envisioning a cataclysmic destruction of the cosmos in the future (e.g., Mark 13:8, 24-25; 2 Pet. 3) or depict the elect as lifted out of the earthly realm to meet the Lord (1 Thess. 4:16-17). Second Peter is perhaps considered the most difficult text (2 Pet. 3-13); it seemingly casts a vision for the final destruction of the earth: "But the day of the Lord will come like a thief, and then the heavens will pass away with a loud noise, and the element will be dissolved with fire, and the earth and the works that are upon it will be burned up" (3:10). Texts such as these have contributed toward indifference among some evangelical groups within Christianity. One example of this critique is articulated by David Orr: "Belief in the imminence of the end times tends to make evangelicals careless stewards of our forests, soils, wildlife, air, water, seas and climate" (Orr 2005 , p. 291). Yet, when these texts are viewed from within a broader biblical context with exegetical and lexical clarification, many scholars conclude that the heat and fire referenced here indicate not destruction but rather cleansing, refining, or revealing (e.g., Lucas 1999; Moo 2006). The theme of God's refining as a means for transformation runs throughout Scripture (e.g., Mal. 3:2; Zech. 13:9), and fire symbolizes God's holiness and power (e.g., Deut. 4:24, 9:3; Heb. 12:29). While cataclysmic end-time texts have tended to pose a challenge for theologians who seek to instill motivation to care for the earth, other texts, most notably Revelation 21-22, envision a continuity of the present earthly realm into a heaven-like future, readings that focus on earthly restoration or transformation. Barbara Rossing has contributed significantly toward ecocritical readings of eschatological texts in Revelation (Rossing 2005, 2010). The reality of such tension between texts is succinctly summarized by D. Horrell: "The ambivalence of the texts and their openness to diverse interpretations means that various construals of 'biblical teaching' are possible" (Horrell 2010, p. 119). These tensions also affirm why simply reading biblical texts is not sufficient for creating a responsible ecotheology; drawing upon ecclesiastical tradition, interdisciplinary insight, personal experience, and reason is essential to inform how ancient sacred texts can speak a life-giving message into our context.

Within the field of pnenumatology recent progress has been made when considering how science can inform traditional theological frameworks. This strategy has induced stimulating new questions about the relationship of God with creation. Particularly within the Western evangelical tradition, Christians and professional theologians have often conceptualized the Spirit as primarily engaged in human transformation and building the Christian community. Influenced, in part, by a dualism between Spirit and matter, this perspective views the Spirit as less involved with or even completely detached from the other-than-human created order. The combination of ecology with Spirit, ecopneumatology, prompts questions such as the following, which are paving the way for groundbreaking work on the relationship of the Spirit with ecology: Where is the Spirit of God in an evolving universe? In what ways might scientific explanations of life expand the theological understanding of general divine action through the Spirit? As theologian and biochemist C. Southgate uses the language of evolutionary biology to conceptualize the Trinitarian function of God in creation, "The Father in creation both draws onward the ever-shifting distribution of peaks in the fitness landscape, through the unfolding creative work of the Logos, and encourages organisms, through the power of the Spirit, in their exploration of that landscape, giving rise to new possibilities of being a self" (Southgate 2008, p. 61). Similarly D. Edwards utilizes evolutionary science to affirm a form of Trinitarian panentheism. Here the Spirit makes space for the processes of the emerging and evolving universe to take place and move forward toward the eschatological new creation (Edwards 2004, pp. 130-42). This approach provides a point of discussion of the mutual relations and communion within the Divine while exploring what constitutes the relationship of the Spirit's cooperative work with the laws of nature, drawing creatures and the universe toward communion with God so that "God may be all in all" (1 Cor. 15:28). These analogies give a new level of understanding to texts such as Romans 8 that present the Spirit as one who in self-limiting love and compassion comes alongside 
the creation that is waiting and groaning as in birth pangs, anticipating an eschatological freedom from bondage and death (Rom. 8:19-23). Each of these examples demonstrates how theological categories, when viewed from an ecologically sensitive vantage, has potential for revealing rich contours of ecological wisdom otherwise unnoticed in sacred texts.

\section{Conclusions}

In a time when the evidence of growing environmental degradation exasperated by human neglect and consumer patterns seems both undeniable and daunting, people of faith are revisiting the multi-textured resources of ancient texts, traditions, and doctrine seeking a fresh and relevant message. In this brief article, I have surveyed a few of the key reading strategies and ecological hermeneutical approaches within the expanding and important field of ecotheology. Such resources enable scholars, clergy, lay men and women to read ancient texts with ecological lenses which result in fresh biblical insights that inform environmental praxis. Recent theological work considers how key doctrinal constructs such as soteriology, eschatology and pneumatology can be reformulated to reflect the biblical themes of the universal, cosmic scope of God's love and redemptive purposes. Each of these trajectories provide encouragement for readers of Scripture to contemplate new ways of thinking about the earth and the human relationship to it and to discern, value, and listen to the entire earth community as the household of God and God's good creation.

Funding: This research received no external funding.

Conflicts of Interest: The author declares no conflict of interest.

\section{References}

Bauckham, Richard. 2010. The Bible and Ecology: Rediscovering the Community of Creation. Waco: Baylor University Press. Bauckham, Richard. 2011. Living with Other Creatures: Green Exegesis and Theology. Waco: Baylor University Press. Berry, Wendell. 2002. Christianity and the Survival of Creation. In The Art of the Commonplace. Edited by Norman Wirzba. Berkeley: Counterpoint, pp. 305-20.

Berry, R. J., ed. 2006. Environmental Stewardship: Critical Perspectives-Past and Present. New York: T\&T Clark.

Brown, William. 2010. The Seven Pillars of Creation: The Bible, Science, and the Ecology of Wonder. Oxford: Oxford University Press.

Conradie, Ernst M. 2006. Christianity and Ecological Theology: Resources for Further Research. Study Guides in Religion and Theology 11. Stellenbosch: SUN Press.

Conradie, Ernst M. 2007. The Whole Household of God (oikos) Some Ecclesiological Perspectives: Part 1 \& 2. Scriptura 94: 1-28.

Dalton, Ann Marie, and Henry Simmons. 2010. Ecotheology and the Practice of Hope. New York: SUNY.

Davis, Ellen F. 2009. Scripture, Culture and Agriculture: An Agrarian Reading of the Bible. Cambridge: Cambridge University Press.

Deane-Drummond, Celia. 2017. A Primer in Ecotheology: Theology for a Fragile Earth. Oregon: Cascade Books.

DeWitt, Calvin B. 2000. Creation's Environmental Challenge to Evangelical Christianity. In The Care of Creation: Focusing Concern and Action. Edited by R. J. Berry. Leicester: InterVarsity, pp. 60-73.

Edwards, Denis. 2004. Breath of Life: A Theology of the Creator Spirit. New York: Orbis.

Fretheim, Terence. 2005. God and World in the Old Testament: A Relational Theology of Creation. Nashville: Abingdon. Habel, Norman C. 2001. The Earth Story in the Psalms and Prophets. The Earth Bible Series 4; Sheffield: Sheffield Academic Press.

Habel, Norman C. 2008. Introducing Ecological Hermeneutics. In Exploring Ecological Hermeneutics. Edited by Norman C. Habel and Peter Trudinger. Atlanta: Society of Biblical Literature, pp. 1-8.

Habel, Norman C. 2009. An Inconvenient Text: Is A Green Reading of the Bible Possible. Adalaide: ATF Press.

Habel, Norman C., and Vicki Balabanski, eds. 2002. The Earth Story in the New Testament. The Earth Bible 5. Sheffield: Sheffield Academic Press. 
Habel, Norman C., and Shirley Wurst, eds. 2000. The Earth Story in Genesis. The Earth Bible Series 2; Sheffield: Sheffield Academic Press.

Habel, Norman C., and Shirley Wurst, eds. 2001. The Earth Story in Wisdom Traditions. The Earth Bible 3. Sheffield: Sheffield Academic Press.

Habel, Norman C., ed. 2000. Readings from the Perspective of the Earth. The Earth Bible Series 1; Sheffield: Sheffield Academic Press.

Hessel, Dieter T., and Rosemary Radford Ruether, eds. 2000. Christianity and Ecology: Seeking the Well-Being of Earth and Humans. Cambridge: Harvard University Center for the Study of World Religions Publications.

Horrell, David G. 2010. The Bible and the Environment: Towards a Critical Ecological Biblical Theology. London: Equinox.

Horrell, David G., Cherryl Hunt, Christopher Southgate, and Francesca Stavrakopoulou, eds. 2010. Ecological Hermeneutics: Biblical, Historical and Theological Perspectives. London and New York: T\&T Clark.

Jenkins, Willis. 2009. After Lynn White: Religious Ethics and Environmental Problems. JRE 37: 283-309. [CrossRef] Johnson, Elizabeth A. 1993. Women, Earth, and Creator Spirit. Mahwah: Paulist Press.

Johnson, Elizabeth A. 2014. Ask the Beasts: Darwin and the God of Love. New York: Bloomsbury.

Knierim, Rolf P. 1995. The Task of Old Testament Theology: Substance, Method and Cases. Grand Rapids: Eerdmans.

Law, Jeremy. 2010. Jürgen Moltmann's Ecological Hermeneutic. In Ecological Hermeneutics: Biblical, Historical and Theological Perspectives. Edited by David G. Horrell, Cherryl Hunt, Christopher Southgate and Francesca Stavrakopoulou. New York: T\&T Clark.

Leese, J. J. Johnson. 2018. Christ, Creation and the Cosmic Goal of Redemption: A Study of Pauline Creation Theology as Read by Irenaeus and Applied to Ecotheology. New York: T\&T Clark.

Lucas, Ernest. 1999. The New Testament Teaching on the Environment. Transformation 6: 93-99. [CrossRef]

Manning, Russell R., ed. 2013. The Oxford Handbook of Natural Theology. Oxford: Oxford University Press.

Moltmann, Jürgen. 1985. God in Creation: The Gifford Lectures 1984-1985: An Ecological Doctrine of Creation. Translated by M. Kohl. London: SCM.

Moo, Douglas J. 2006. Nature in the New Creation: New Testament Eschatology and the Environment. JETS 49: 449-88.

Orr, David W. 2005. Armageddon versus Extinction. Conservation Biology 19: 290-92. [CrossRef]

Rossing, Barbara. 2005. For the Healing of the World: Reading Revelation Ecologically. In From Every Tribe, Tongue, People, and Nation: The Book of Revelation in Intercultural Perspective. Edited by David Rhoads. Minneapolis: Fortress.

Rossing, Barbara. 2010. God Laments with Us: Climate Change, Apocalypse and the Urgent Kairos Moment. Ecumenical Review 62: 119-30. [CrossRef]

Santmire, Paul. 1985. The Travail of Nature: The Ambiguous Ecological Promise of Christian Theology. Theology and the Sciences. Philadelphia: Fortress.

Santmire, Paul. 2000. Nature Reborn: The Ecological and Cosmic Promise of Christian Theology. Minneapolis: Fortress. Santmire, Paul. 2017. Behold the Lilies: Jesus and the Contemplation of Nature. Eugene: Cascade Books.

Schutz, Paul J. 2018. From Creatureliness to a Creation Imagination. The Other Journal: An Intersection of Theology and Culture 28: 10-19.

Snyder, Howard A., and Joel Scandrett. 2011. Salvation Means Creation Healed: The Ecology of Sin and Grace, Overcoming the Divorce between Earth and Heaven. Eugene: Cascade Books.

Southgate, Christopher. 2008. The Groaning of Creation: God, Evolution, and the Problem of Evil. Louisville: Westminster John Knox.

Stone, Ken. 2017. Reading the Hebrew Bible with Animal Studies. Stanford: Stanford University Press.

Theokritoff, Elizabeth. 2017. Green Patriarch, Green Patristics: Reclaiming the Deep Ecology of Christian Tradition. Religions 8: 116. [CrossRef]

Watson, Francis. 2010. In the Beginning: Irenaeus, Creation and the Environment. In Ecological Hermeneutics: Biblical, Historical and Theological Perspectives. Edited by David G. Horrell, Cherryl Hunt, Christopher Southgate and Francesca Stavrakopoulou. London and New York: T\&T Clark, pp. 127-39.

White, Lynn, Jr. 1967. The Historical Roots of Our Ecologic Crisis. Science 155: 1203-7. [CrossRef] [PubMed] 
Wirzba, Norman. 2006. Living the Sabbath: Discovering the Rhythms of Rest and Delight. Grand Rapids: Brazos.

Wirzba, Norman. 2015. From Nature to Creation: A Christian Vision for Understanding and Loving Our World. The Church and Modern Culture. Grand Rapids: Baker Academic. (CC BY) license (http:/ / creativecommons.org/licenses/by/4.0/). 